\title{
Research on the Guanyin Statues Feminine Appearance in the Tang Dynasty Jing $\mathrm{ZHANG}^{1, \mathrm{a},{ }^{*}}$
}

${ }^{1}$ School of Art and Design, Xi'an University of Technology, ShaanXi, 710054, China; ajingzhang@xaut.edu.cn

Keywords: Tang Dynasty, Guanyin Statues, Bodhisattva's Feminization, Modelling.

\begin{abstract}
It is based on the influence of Chinese traditional culture and main to analyze the origin of Guanyin bodhisattva statues, reasons of Bodhisattva's feminization from the perspectives of facial features, clothes, posture etc. It is purpose the Tang dynasty is golden age of buddhist images and is important period of expression of the Bodhisattva's feminization.
\end{abstract}

\section{Introduction}

The Avalokitesvara is god in the India buddhist system, she is regarded as deity of succouring. Because she is a compassionate and can help people to the other shore. The Avalokitesvara image was the typical representative of Sanskrit Bodhisattva, transliterated into "bodhi" at common. As a wide-spreading religious phenomenon, the Guanyin (Avalokitesvara) belief has had an important effect on the history and the culture of China.

What appearance was the original Guanyin (Avalokitesvara)?It is said to have a pair of twin foals, it called double stable god, who they can make the blind surgery, Deadwood flower, Because of its divinity and god of widely spread.[1] With the Buddhism was introduced into China at Han dynasty. The Chinese Avalokitesvara statues was mixed from the Indian Buddhist and Chinese mythology story. With the sinicization of Guanyin belief at the Tang dynasty, The Guanyin modeling become the Chinese feminine appearance and it is accord with Chinese traditional ethics and aesthetic ideas.

\section{Modelling Features of Guanyin Feminine}

\section{Facial Beauty}

The Buddhism Guanyin has female appearance in the Tang dynasty, before the Tang dynasty, the modelling of mostly male form. Because the Guanyin statues was a male originally. With a kind expression in their eyes, varied hand and spellbinding body movement and so on, the Avalokitevara gradually evolved into female image and worshipped in Buddhist temples. First look at the facial features, face round, arch eyebrows, the phoenix eye, rose slightly and silences, small cherry mouth and so on. For example, the cave 220, Mogao Grottoes, the feminization of Guanyin modelling has been completely Chinese women face, small lips, high bun and so on, Bodhisattva's clothing is according to the women of the tang dynasty who is the most popular, these characteristics is noble ladies image. Therefore is also called the "palace doll" as the "Bodhisattva image" at the Tang dynasty.[2]

\section{Body Beauty}

At the Tang dynasty, the feminization of Guanyin modelling has been exaggeratedly 
feature. Such as tiny waist, rounded hip, varied hand postures and so on. The Bodhisattva's head slightly to the right, upper body slightly to the left, formed the " $S$ " shape, this kind of posture will make viewers feel visual aesthetic pleasure. Also reflected the Chinese humanistic thoughts on openness and respect for human nature. Such as The Mogao grottoes 57th of Guanyin bodhisattva is such a shape.

\section{Clothing Beauty}

Bodhisattva clothing generally have a tiara, shawls, wreaths dress etc. These clothes are prince dressed up in ancient India period. But these clothes is the adornment of the feminine characteristics at Chinese Tang culture, it is also to wear which is noblewomen. For example, The Brocade Scarfis the ancient women put up on the shoulder, intertwined with arms long silk. The GuanYin modelling fashion style in the Tang dynasty is to wear skirt, half-sleeves, brocade scarf and wear a high skirt with waistband at the armpit. At the same time Guanyin stands on the lotus throne with the adorned by tassels and red dhoti. The unity of garment beauty in terms of form and content makes it possible for the aesthetic demand to be reflected by visual sense, conveying a beauty sense.

\section{Regional Culture of the Guanyin Feminine Modelling \\ Due to the Confucian Culture and the Taoism Culture}

The Confucian culture and Taoism culture has long history in traditional Chinese culture and it is a core concept of Confucianism. Which advocates to obey not only the parents but also all the ruler, especially to obey the raising mother. In the Mahayana Buddhism, the four Bodhisattvas were each made for a special purpose, the Guanyin of mercy Lord, she is the symbol of great mercy. The "compassion" represents the male culture in the ancient Indian culture, but the "compassion" is understood to be unique to women a kind of quality under the background of Chinese traditional culture.

<Etymology Dictionary>explains "kindness", it is main to the "mother", "compassion" is mercy and compassion in the Buddhism. [3] So the mostly Bodhisattva modeling will be made to feminine character. Such as long hair, long skirt, pierced earring, exaggerated abdomens and buttocks and so on. Because feminine of Buddhism modelling have big appeal from the psychological and emotional .At the same time feminine statue is easier to show compassion heart, meet the demand of woman's heart. Also conform to the father of Taoism point, The Laozi said: "women is to educate the universe while a perennial "the mother instrument", reflects the Chinese common pursuit of "mothering".[4]

\section{Due to the Yin and the Yang Culture}

The culture of the Yin and Yang is the most original and characteristic invention of Chinese culture. It came from "Yi", and both Confucianism and Daoism take it as the scripture. In Chinese culture philosophy, The Yin and the Yang are primary structural genes. Which are also two critical elements for the existence and dependence of everything in the world, the Yin-Yang thoughts had great effects on the Guanyin modelling in China. So Guanyin modelling no longer limited to the original sound of Buddhist content, but dissolved into the Chinese culture of Yin and Yang and aesthetic features. Bodhisattva statues of the feminine in accordance with the aesthetic ideal of Chinese culture of Yin and Yang has created a new image, was given the women of feminine beauty, apparel have elegant feeling, contrasts with the Buddha virile beauty, 
with beautiful, vivid image foil the grand and solemn of the Buddha.

\section{Due to the Folk Cultural}

The folk culture is a very precious culture resource, which plays an important role in moral education. So the Buddhist belief is also including folk beliefs of ordinary people. Chinese people's belief in Buddhism combined Chinese folk culture to the Guan Yin modelling. Such as she symbolizes purity, seated with legs crossed, holding a full-blown lotus. So the modelling of Bodhisattva's feminization can embodies the psychology of Chinese consciousness and beauty of pursuit and rich religious culture connotation, broadening the understanding of national culture for the Chinese public.

\section{Conclusion}

Engels said: "all religions are dominating the external forces of the People's Daily life which is the reflection of fantasy in the mind, there will different experience in the different nation." [5] The evolution of the feminine of the GuanYin image shows Chinese traditional culture not only to absorb foreign culture, but also came with the purpose of Buddhism statues, the Buddhism's historical development and accord with China's national conditions.

\section{Acknowledgement}

This research was financially supported by Department of Education of Shaanxi Province and Department of Culture of Shaanxi Province. (16JK1531, SY2016047)

\section{Reference}

[1] Guang-xing XIA, Belief in GuanYin and Creation of literature in Tang dynasty, J.Journal of Shanghai Normal University.2003.(9)100-104.

[2] Min LI, Bodhisattva's Crown of The Early-Tang Period in The Dunhuang Art of Mogao Grottoes, J.Dunhuang Research.2004.(12) 88-90.

[3] Wei-juanLENG, Dunhuang Bodhisattva portraits with feminine and local cultural characteristics, J. Literature and Art Forum.2011.(1)110-111.

[4] Hua-dang XU, China's traditional image drawings---the bodhisattva [M].China Forestry Publishing House, 2015.

[5] Xiao-fei QI, Thinking of religious positive about harmonious society, J.Religious Culture of World. 2011.(2) 5-11. 